\title{
CONCEPTUAL VIEWS ON REFORMING THE INSTITUTION OF ARBITRATION
}

\section{Viktor Tanasiienko ${ }^{1}$}

DOI: https://doi.org/10.30525/978-9934-26-050-6-27

On January 29, 2019, the Cabinet of Ministers of Ukraine supported the Draft Law of Ukraine «On Amendments to Certain Laws of Ukraine (on Improving the Procedure for Establishment and Activity of Arbitration Courts in order to Restore Confidence in Arbitration)» developed by the Ministry of Justice [1].

The main innovations of this bill in terms of amendments to the Law of Ukraine «On Arbitration Courts» are:

1) establishment of new requirements to the founders of arbitration courts, in particular:

the arbitral tribunal may be formed by the founders, whose term of office until the formation of the arbitral tribunal must be more than 5 years;

the founders must provide the arbitral tribunal with premises and material means for carrying out its activities;

the founders of both existing and newly established arbitration courts must obtain an opinion of the Arbitration Chamber of Ukraine (hereinafter - ACU) on the founder's compliance with the requirements of this Law and register changes in information about the arbitration court;

the founders are obliged to pay organizational fees for the maintenance of ACU in «equal and proportional amounts», the «purpose» and frequency of payment of which are determined by the decision of the All-Ukrainian Congress of Arbitrators;

2) change in the status and powers of the ACU:

ACU acquires the status of a legal entity, which is «maintained at the expense of organizational contributions of the founders of permanent arbitration courts, in equal and proportional amounts approved by the AllUkrainian Congress of Arbitration Judges, as well as from other sources not prohibited by law»;

ACU provides a binding opinion for all permanent arbitration courts on the compliance of the founder of the permanent arbitration court with the requirements of this law. In case of non-compliance by the founder of the permanent arbitration court established by law, the requirements of the ACU

\footnotetext{
${ }^{1}$ Research Institute of Private Law and Entrepreneurship named after Academician F.G. Burchak NALS of Ukraine, Ukraine
} 
apply to the state registration body with a statement of violation by the founder of the law in order to terminate the activities of such arbitration court;

3 ) changes in the jurisdiction of the arbitral tribunal:

instead of the existing in paragraph 14 of Part 1 of Art. 6 of the Law of Ukraine «On Arbitration Courts» (hereinafter - the Law) rules on exclusion from the jurisdiction of the arbitral tribunal of disputes in cases of consumer protection consumers «

it is envisaged to delete item 7 part 1 of Art. 3 years from the day following the day of publication of amendments to the law. 6 of the Law, according to which the arbitral tribunal has no jurisdiction in disputes over real estate, including land [2].

Unfortunately, this bill has not been discussed with the founders of the permanent arbitration courts, to which the bill assigns new responsibilities. Obligation to discuss normative legal acts with the object of their influence is provided in Articles 5, 6, 9 of the Law of Ukraine «On Principles of State Regulatory Policy in the Sphere of Economic Activity», paragraphs 12.13 of the Cabinet of Ministers Resolution on Ensuring Public Participation in Formation and Implementation of State Policy «dated November 3, 2010 № $996[3 ; 4]$.

The current Arbitration Chamber of Ukraine also did not discuss this bill.

The goal stated in the bill - «restoring confidence in arbitration» - is not relevant. The number of working arbitration courts and the number of cases considered by them is insignificant. What is relevant is not distrust of arbitration courts, but low awareness of their capabilities, legal restrictions on the jurisdiction of arbitration courts, unstable case law of state courts in assessing the grounds for revoking arbitral awards and issuing writs of execution to enforce their decisions, which reduces their attractiveness to parties to the dispute.

The number of arbitration courts that heard at least one arbitration case in 2017-2018 is only 39, which is less than $10 \%$ of the number of local state courts, and the number of arbitration cases is less than $1 \%$ of the number of cases heard by local courts. state courts.

Regarding the 39 arbitration courts operating during the last 5 years, we do not know of any decision of the state court that would testify to the actions of the judges of these arbitration courts, which would indicate a loss of confidence in them. The population does not know anything about the remaining almost 500 registered arbitration courts that do not operate, but they are inactive and cannot create distrust in them. Excluding even all 500 non-functioning arbitration courts from the register will in no way increase the activity of 39 existing courts, or increase the level of trust in arbitration courts. 
As for the 39 existing courts, the fact of their positive activity and trust in them is recognized by the parties to the dispute, who apply to these courts for dispute resolution. Obtaining a positive conclusion of the ACU is superfluous. If these courts eventually lose the credibility of the parties to the dispute, they will cease to apply to these courts for dispute resolution. Similarly, obtaining a positive opinion of the ACU by the founders of the arbitral tribunal is not a guarantee that such a court will become active or the already active court will not lose credibility in the future [5].

Obviously, obtaining a positive conclusion of the ACU on the compliance of the founders of the court with the new requirements of the law does not directly affect the level of confidence in the arbitration court, as disputes are considered not by the founders but by arbitrators! If the founder of the arbitral tribunal wants the arbitral tribunal created by him to consider disputes, he creates all the necessary conditions for this. If he does not want to, he punishes himself by the inaction of such a court.

In addition, the bill does not specify what criteria must be met by the premises to be provided to the arbitration court by the founders, what material support of the arbitration court by the founders is sufficient, what are the legal consequences of termination of "periodic» ACU funding by the founder and so on. The lack of criteria defined by law gives rise to subjectivity in the provision of a mandatory draft opinion of the ACU.

As for the proposed amendment to the wording of paragraph 14 of Part 1 of Art. 6 of the Law and exclusion from the jurisdiction of the arbitral tribunal of disputes over consumer claims instead of the existing exclusion of disputes in consumer protection cases, both new and existing version of this paragraph directly contradicts the right of a person to elect a state or arbitral tribunal. This right of a person is stated in paragraph 3.1 of the decision of the Constitutional Court of Ukraine of 10.01.2008 in case № 1-3/2008 «On the tasks of the arbitration court» with reference to Art. 55 of the Constitution of Ukraine [6].

Exclusion from the jurisdiction of the arbitral tribunal of disputes concerning the protection of consumer rights or disputes over consumer claims is contrary not only to Art. 55 of the Constitution of Ukraine, but also the Directive of the European Parliament and of the Council № 2013/11/EU of 21.05.2013 «On alternative dispute resolution with consumers», which directly provides for the possibility of litigation with the participation of consumers in a private court [7].

The exclusion of consumer protection disputes from the jurisdiction of the arbitration court in 2011 led to the suspension of several arbitration courts established by public associations for consumer protection. 
In 2015, the Supreme Court of Ukraine further limited the jurisdiction of arbitration courts. Considering several cases of revocation of arbitration decisions, the Supreme Court concluded that disputes concerning consumer protection include disputes over creditors' claims against consumers for protection of creditor's rights. The result of this conclusion of the Supreme Court was a tenfold reduction in the number of disputes considered by arbitration courts.

The proposed amendments to the Law will not contribute to the support of working arbitration courts, increase the number of disputes considered by them. The activity of the reduced number of arbitration courts under this bill will remain even more unknown to the majority of the population. The purpose of the bill should be to support the working arbitration courts, to promote greater consideration of arbitration cases, and not to strengthen the requirements for the founders of the arbitration court, which will reduce the number of arbitration courts and, accordingly, reduce their activity and attractiveness for litigation.

Thus, it is possible to follow the legislator's attempt to make changes that would affect only the process of formation of the arbitration court, but not the reform of the institution of arbitration in general. First of all, the changes must be fundamental, establish a new procedure for the appointment of arbitrators, introduce the concept and process of certification of arbitrators, the procedure for bringing arbitrators to justice, a new division of cases of arbitrators. Instead, these changes are not even spelled out in these bills [8].

\section{References:}

1. Draft Law on Amendments to Certain Laws of Ukraine (on Improving the Procedure for Establishment and Activity of Arbitration Courts in order to Restore Confidence in Arbitration) of 10.02.2020 № 3045. URL: http://w1.c1.rada.gov.ua/ pls/zweb2/webproc4_1?pf3511=68103

2. Law of Ukraine 'On Arbitration courts' of 11.05.2004 № 1701-IV (Vidomosti Verkhovnoi Rady Ukrainy (VVR), 2004, № 35, p.412). URL: https://zakon.rada.gov.ua/ laws/show/1701-15\#Text

3. Law of Ukraine 'On the principles of state regulatory policy in the field of economic activity’ of 11.09.2003 № 1160-IV (Vidomosti Verkhovnoi Rady Ukrainy (VVR), 2004, № 9, p.79). URL: https://zakon.rada.gov.ua/laws/show/1160-15\#Text

4. Decree of Cabinet Of Ministers of Ukraine 'On ensuring public participation in the formation and implementation of public policy' of 03.11.2010 № 996. URL: https://zakon.rada.gov.ua/laws/show/996-2010-\%D0\%BF\#Text

5. Arbitration courts in Ukraine: state of development, statistics, practice and prospects. URL: https://dejure.foundation/library/treteyski-sudy-v-ukraini-stanstatystyka-praktyka-ta-perspektyvy 
6. Solution of the Constitutional Court of Ukraine 'Case No. 1-3 / 2008' of 10.01.2008 № 1-pп/2008. URL: https://zakon.rada.gov.ua/laws/show/v001p71008\#Text

7. Directive 2013/11/EU of the European Parliament and of the Council of 21 May 2013 on alternative dispute resolution for consumer disputes and amending Regulation (EC) No 2006/2004 and Directive 2009/22/EC (Directive on consumer ADR). URL: https://eur-lex.europa.eu/legal-content/EN/TXT/?uri=celex:32013L0011

8. Draft Law on Amendments to Certain Laws of Ukraine (on Improving the Procedure of Arbitration Courts and Increasing the Liability of Arbitration Judges in order to Restore Confidence in Arbitration) of 26.02.2020 № 3045-1. URL: http://w1.c1.rada.gov.ua/pls/zweb2/webproc4_1?pf3511=68253 